\title{
A Digital Literacy for the Future: ICT as Separate Subject
}

\author{
Siri Fyksen \\ Primary School Teacher in Oslo, Norway \\ Student at Oslo and Akershus University College of Applied \\ Sciences' Master Programme in ICT Supported Learning
}

\begin{abstract}
This paper focuses on teaching in primary school in sub-Saharan Africa where education in digital literacy seems to need focus. As a teacher in the Norwegian primary school the author has experience in teaching digital literacy. The paper elaborates on these experiences when identifying and defining a digital literacy that can be applied to the school system in sub-Saharan Africa, evaluated to physical and economical frame factors. The author has gained knowledge of these frame factors through a literature review on journal papers and Internet searches performed during spring 2011.
\end{abstract}

Keywords: Curriculum, Development, Digital Divide, Digital Literacy, Education, ICT, Learning, Primary School, Strategic Planning, Sub-Saharan Africa, Teaching.

\section{Introduction}

Digital literacy should be a part of the curriculum for children in all parts of the world, in order to bridge the digital divide both globally, among pupils within the same country, and even among schools and classes. We know that several challenges need to be met when it comes to ICT integration in education, especially in sub-Saharan Africa where emphasis on basic human needs is critical, and where the diversity of linguistic- and local factors are especially challenging.

To cope with challenges regarding ICT integration in education in general, and in subSaharan Africa in particular, presupposing that a minimum of technical infrastructure is available, a framework for ICT as a separate subject is proposed. The proposal is based on the author's own experiences from teaching digital literacy in a Norwegian primary school, where ICT in teaching and learning in some schools evolves slowly from the use of digital tools in subjects to inclusion of an additional digital literacy consisting of ICT as a separate area of focus. The offspring of the model is the acknowledged need of available time, technology and expertise.

To achieve implementation of ICT as a separate subject in sub-Saharan Africa, it's likely that teachers' education will be forced to change, in order to focus on strategies, curriculum and implementations in this area. The entire school system, in fact, will have to adapt to the changes.

Throughout the first chapter of the article, digital literacy is discussed as a term. As a foundation for adaptation to sub-Saharan Africa, the second and most comprehensive section describes the current ICT situation in Norwegian primary school, as experienced by the author. In the following section, the ICT situation in Africa is briefly described, and concrete recommendations to implementation of the proposed ICT model in sub-Saharan African primary schools are identified. Finally, a portion of the article dwells on prerequisite factors for success of the proposed model in this part of the world.

\section{Digital literacy in teaching and learning}

The world is changing, and ICT plays an increasingly important role in people's lives and in socio-economic development. ICT is a historic technology that emerged and was adopted quickly; this has provided, as Storsul et al. consider it, a unique potential for teaching and learning activities in schools [1].

In 1986 Fougner and Søbstad expressed that media development would change teaching practice in several ways [2]. Expressed through this context, new practices in teaching and learning have occurred, and the concept of digital literacy has appeared. The relatively new definition has several interpretations, leading to uncertainty about what it means and challenges in teaching and learning. One of the issues is:

- What should training in digital skills consist of, when there is uncertainty about what digital literacy actually is? 
To achieve understanding of the phenomenon "digital skills training," some different interpretations are presented in the following ways: Literacy is a broad definition that includes both reading and writing. Literacy is frequently used in combination with prefixes like media-, digital- or multi-. Buckingham (2003) defines media literacy as "the ability to access, understand and create communications in a variety of contexts" [3]. Stables (2003) claims the concept of literacy in the present time has a double meaning:

- $\quad$ On the one hand, to be literate is the ability to read and write (or to decode and encode sign systems, for immediate, and often highly functional, purposes); on the other hand it is to be valued in a world that values literacy [4].

From this point of view the term of literacy is no longer all about the ability to read and write; introduction of ICT into society includes knowledge and abilities related to ICT. Buckingham (2003) expresses the vision like this:

- $\quad$ In the modern world media literacy is just as important for young people as the more traditional literacy of print. Media education, then, is the process of teaching and learning of media; media literacy is the outcome-the knowledge and skills learners acquire [3].

Both Paul Gilster and Kathleen R. Tyner have written books about digital literacy. Gilster (1997) claims that "Digital Literacy is the ability to understand and use information in multiple formats from a wide range of sources when it is presented via computers" [5].

Tyner (1998) points out that none of the existing definitions of digital literacy are accurate enough- or comprehensive enough to convey a broad understanding of the required expertise in a digital world. She chooses to divide digital literacy into tool literacy and literacy of representation [6]. From his point view Erstad (2005) expresses that digital literacy has to include skills, knowledge and attitudes required in order to relate to digital media [7].

Derived from these experiences, digital literacy is all about the ability to use digital tools; to have a sufficient understanding of the technology's function in, and influence on, society, one could define it as the expertise with ICT and in ICT. According to Øgrim and Beck (2009) there are three words that can be used to highlight the knowledge students should possess with regard to ICT: Use, Understand and Change [8].
McKenna et al. (2006) substantiate the view of technology and literacy as inseparable entities, despite the technology's high change rate and additional challenges associated with interpretation of digital literacy as a term as follows:

- $\quad$ The effects of technology on literate activity have been both sweeping and subtle, marked by an increasing variety of changes that are difficult to evaluate and project. Perhaps the only prediction that can be offered with certainty is that the impact of technology is irreversible. Specific changes may come and go, but literacy and technology seem inextricably linked [9].

Digital literacy refers to a field of complexity that requires skills and expertise that demands targeted and continuous education in order to gain knowledge and skills. Even though several years have passed since ICT was introduced into society and to the school system in Norway, natural integration of ICT into teaching and learning is far from having been achieved. Perhaps one of the reasons is a shortcoming in the understanding of the concept of digital literacy and the importance of being digitally literate in a digital community. The author's experience from teaching ICT points to digital literacy as a separate subject best taught by teachers specially trained to face existing challenges.

The transformation of interpreting literacy is not reserved for wealthy parts of the world; in order to bridge the digital divide, societies in developing countries need introduction to the "new method" of reflection. It might provide these countries a competitive edge to overcome less-fortunate strategies and implementations caused by an "oldfashioned” interpretation of the literacy concept. In the introductory phase of ICT, sub-Saharan Africa might find it more efficient to view it as a separate subject and develop strategies that reflect this. In order to take part in the information society, it's urgent for people in "the South" to achieve digital skills and reveal the mutually dependent relationship between technology, literacy and society. This awareness, combined with the proposed ICT model in teaching and learning, will most likely contribute to a faster bridging of the divide.

With the recognition that ICT, including technological infrastructure and trends, will be subject to change at high speed into the future, it is necessary to stay updated and aware of the technology in order to be an active participant in the communication society. 


\section{Digital literacy and primary school in Norway}

\subsection{Digital literacy in curriculum}

In Norway’s primary school curriculum, published in 2006, digital literacy is discussed as a basic skill together with oral skills and the ability to read, write and calculate. The basic skill is to be built through use of digital tools in all subjects, essentially in the same way that the other basic skills are naturally integrated into all subjects.

The centrally prepared curriculum leaves it to each school to interpret how to approach ICT within subjects, which results in various approaches to digital literacy-leading to different levels of knowledge among the pupils. According to Erstad (2007), this means that schools are oriented towards development projects on the ICT in very different ways [10]. As a consequence of this, Øgrim and Beck (2009) have discovered a tendency towards less focus on ICT in teaching, and they fear fragmentation of responsibility and lack of system, variation and progression in educational programs [8]. Moreover, schools are often insecure in their use of ICT, Erstad points out, and integrating use of digital tools into learning activities seems to be one of the challenges in Norway's meeting with digital literacy [7].

From this point of view, something fundamental is missing from the Norwegian primary school curriculum, and there seem to be challenges in the approach to ICT. In order to safeguard graded basic skills in digital literacy, it must be guided by available time, technological infrastructure and expertise. The increasingly varied educational practices and differing methodological approach when it comes to digital literacy argues for the necessity of a new and more tangible curriculum applicable to the school system. A centrally, nationally or internationally designed curriculum for ICT as a separate subject might be the solution for developing the best practice at the present time and could function as a kind of "user's manual" for fundamental ICT. These reflections provide a favourable starting point for education in digital literacy in sub-Saharan Africa, as preparation of the curriculum for teaching and learning is presumably based on outcome of methods already implemented elsewhere with questionable degrees of success.

\subsection{Approach to digital literacy—a backdrop}

The introduction of use of digital tools as a basic skill in education in Norway was a vote of confidence to the view of ICT as a positive contribution to teaching and learning activities. The concern of "media's apparent lack of cultural value"
[3] had faded amongst doubters and been replaced by a modern approach to ICT. However the terminology in the curriculum is considered by some to be incomplete and expressed in an unclear manner, with a lack of specification issues that involve the "what, why, how and to whom" introduction of the new basic skill. As already expressed, these weaknesses constitute a basis for a diversity of possible interpretations, which in turn leads to frustration, disagreements and various practices.

The background for the formulations in the curriculum might have had its starting point in scholars' and scientists' advanced and still ongoing discussions including development of "standards for digital literacy"-built through interpretations of presumed content in digital literacy as a term. On the one hand, inclusions of necessary skills for use are highlighted, and on the other hand, knowledge building as a result of social processes through evernew technologies is emphasized. Erstad (2007) refers to Tyner (1998), Gilster (1997) and Lankshear and Knobel (2006) when questioning "tool literacies" as the most important basic media skill.

- $\quad$...because it first and foremost focuses on mastering the technology itself and apart from the social practice, in which use of theses media appear, and the importance of valuing learning as an extension of these social practices rather than just value learning specific technique [10].

Some critics believe ICT in relation to school environment is out of step with the development in society in general, and designate the school's lack of adaptability as the scapegoat. When Somekh and Mavers (2003) criticize the school's inability to change in the article "Mapping learning Potential: students' conception of ICT in their world" and argue for an old-fashioned system, they refer to Papert, amongst others. He claims that the school hasn't been able to adapt to changes in patterns of life as a result of ICT, as is the case with several digitized out-of-school processes of today's world. Somekh and Mavers explain the reason and outcome of the phenomena through the principles of separation of powers in the school system:

- The power relations that govern the behavior of teachers and students in schools, and schools' own powerlessness in all countries to move outside the structures and practices of educational systems, encapsulate them in a time warp [11].

Additional explanations to the formation of content related to ICT in a curriculum might lie in the overall design of the document, where the main goals are meant to be broken down into targets developed for 
local conditions. When use of digital tools was presented as a new basic skill, there seemed to be an inadequate focus on dimensions including the skill concept, constituting a poor overall picture of necessary skills included in the knowledge model at each school. Being aware that the field was a relatively new area of knowledge to the majority of school workers, the local decomposing processes might have been affected by the lack of expertise.

It's stated that several scenarios might have affected introduction of ICT into the Norwegian school system, even though the intention might have been to delegate the responsibility of interpreting the goals that include the use of digital tools to each school, with an underlying idea of making them tools from their own perspective. Presumably such confidence would create ownership and accountability. Just as likely, an underlying desire was to move beyond fixed limits and patterns into a socio-cultural learning approach, which supports the use of technology as a tool of enhancing the learning process. In connection with this interpretation of the terminology used in the curriculum, another possible influencing factor was that the developers leaned toward the expert statements of disliking the focus on "the skill factor" of ICT. From this point of view, "learning can be understood as a process where people appropriate parts of the knowledge and skills developed by the community" [12].

Although the Norwegian school system welcomed the concept of ICT in teaching and learning in 2006, and in good faith introduced the basic skill use of digital tools "as is," other unexpected (or unplanned for) challenges were revealed and triggered discussions in the wake of the introduction. However, it appears that some schools have developed sufficient procedures due to the introduction of ICT and offer adequate education and information to teachers and students, but from the author's perspective, this isn't representative of an overall picture of Norwegian schools concerning this matter. For various reasons ICT as a natural part of several schools' life has failed, and expectations for the students' ability to use digital tools as a basic skill is not met. Overall, the introduction process seems to be delayed in several areas at several schools, and sub-Saharan Africa has the competitive advantage through its ability to identify and then avoid some of the challenges and obstacles [13].

\subsection{Digital literacy and local arrangements}

Although ICT in Norwegian primary school isn't considered as a separate subject with centrally developed curriculum and goals, several schools have chosen to work out their own curriculum with customized goals for digital literacy as a separate area of focus. Factors influencing this solution are partly described earlier in the article, but lack of access to digital tools is another practical factor. In 2010-2011 there was an average of 3:1 students per computer in Norwegian primary schools [14].

In order to challenge the so-called fifth basic skill, which includes the ability to use digital tools, students need constant access to a PC. Somekh and Mavers (2003) encourage more emphasis on ICT as a natural part of students' learning process in subjects. They also highlight "a laptop for each" as a required tool but are aware that this is not feasible for most schools at this point in time. However, they have a positive attitude towards the future in this context:

- $\quad$ Reduction in the cost of lightweight laptops may soon lead to all students having constant access to ICT at school and at home” [11].

Lack of, or limited access to, technologies in schools causes problems in keeping up with the ICT development in the rest of society. With this in mind during the ongoing implementation phase (which both weaknesses and challenges posed to students, teachers and schools), it's advisable to offer digital skills training at least once a week. This will contribute to safeguarding basic digital skillsspecific patterns might ensure minimum content, progression and continuity of supply. Such an effort will support a fixed distribution plan for personal computers, and additionally support the quality of knowledge dissemination, as the teacher will know in advance and be confident about the lesson content.

This encouragement is first and foremost aimed at sub-Saharan Africa, where the initial challenges are even more complex and diverse than in Norway, but where a power edge lies in an efficiency-enhanced introductory phase. If politicians, school workers, the private sector and development organizations throughout the entire region pay attention to the main constituents proposed in the model and coordinate their practices, the introduction of ICT in teaching and learning in sub-Saharan Africa probably will face fewer obstacles than in Norway.

\subsection{ICT (timely) integrated in all subjects}

The strategic model with digital literacy as a separate subject in teaching and learning is defined as a "best practice" at the present time, due to the immaturity of the school as a unit, which prevents integration of digital tools into the learning process as a basic skill. Natural integration of ICT in teaching and learning, which has not been fully accomplished in Norway, consists of available technological infrastructure, skilled teachers and an overall positive attitude towards necessary changes in learning practices in response to the introduced technology. 
Considering that "the skills of the digital literate are becoming as necessary as a driver's license" in today's world [5], the ideal condition would be utilization of digital tools, including understanding of the social impact on ICT and vice versa, in the same manner as the use of a pencil. Even though the Norwegian school developmental status isn't ripe for this ideal condition, it's essential to integrate the use of digital tools whenever appropriate. It's proved that digital tools affect school performance and students' digital literacy when used in a systematic, academic and pedagogical manner [13]. The proposed model for introduction, with ICT as a separate area of focus, must be seen as an additional "subject" in order to cope with the challenges the school encounters. In time the school would be capable of relating to the technology in the same manner as other social processes.

\section{The benefit of solid strategic planning (time, technological infrastructure and expertise)}

It has been identified that parts of the school system in general lie behind other sectors of community in terms of utilization of ICT. Papert claims that ICT has influenced a mega change in all parts of society except in the school system [11]. Camacho (2006) calls for a paradigm shift, where communities' cultures grow in such a way that they open to accommodation of the e-world [15]. She claims that crucial factors to the adaptation inability lie in restrictive policies and politics.

In Norwegian schools, the responsibility for strategic ICT planning is mainly transferred to schools locally. Schools invest differently in ICT due to variation in employees' ICT knowledge and skills, and this will necessarily affect the development process when it comes to strategic planning in general and use of digital tools specifically. It seems that one of the main reasons for delay in the ICT integration process can be found in unequal longterm strategic thinking: There is a lack of central control and thereby too many "right" solutions concerned with integration and practice of ICT in teaching and learning. Furthermore, it seems that the ICT planning has been considered as a separate priority entity. Inclusion of ICT in all strategy processes and policies and the ability to affect the larger strategic picture is needed in order to achieve a smooth overall ICT integration.

The resolution model to these challenges, in order to avoid facing of the same problems in sub-Saharan Africa, would be a nationally designed curriculum and integration plan for ICT, as a basis for local adoption. Such strategies can be described as the direction by which each entity would determine its own goals. The goals define desired conditions for the future, while the strategy points out measures taken to achieve these goals. Gottschalk (2002) formulates it in the following manner:

- A critical point for a company is to improve the relationship between IT strategy and the overall strategic focus. The core point for the IT strategic planning is to ensure this link [16].

The basic idea of the aforementioned strategies is to support politicians and schools in the following ways:

- $\quad$ Support long-term strategic thinking

- $\quad$ Prevent bad investments

- Prevent local arrangements

- $\quad$ Prevent diversity and digital divides

- $\quad$ Serve as an overview of the required technological infrastructure

- $\quad$ Serve as a user's manual for skills and knowledge included as foundations in digital literacy

- $\quad$ Provide a picture of what kind of digital literacy teachers' education should offer

- $\quad$ Entail that ICT becomes part of the school culture

- $\quad$ Entail that all employees relate to ICT

Regardless of the intent of the ICT introduction into teaching and learning in Norway, it apparently has several weak points. Strategies and milestones in all projects will necessarily be subject to change or improvement. A flawless innovation simply is not realistic; in this case there are obviously too many pitfalls. Knowledge of the applicable strategic circumstances is valuable to further ICT investments in sub-Saharan Africa. Getting to know the grassroots realties concerning investments and practices of ICT in developed countries can help developing parts of the world to identify potential obstacles and prevent them in the forthcoming development phases of ICT strategies and implementation. The subSaharan school system has the opportunity to take into account cited strengths and weaknesses in order to determine best practice.

\section{ICT in sub-Saharan Africa}

\subsection{Development of ICT}

As a developing part of the world, sub-Saharan Africa is characterized by socio-cultural diversity and complex linguistic factors. The level of poverty is high, as is the prevalence of the HIV/AIDS epidemic. Gender discrimination, repressive regimes and civil wars are other problems.

These conditions led to a low level of economic development and ICT awareness and will of course 
negatively affect integration of ICT in teaching and learning. Up until now, large areas, particularly rural and remote societies, have lacked access to the Internet due to limited bandwidth with bad quality.

The needs in sub-Saharan Africa are diverse and complex. A new model of addressing the digital divide is needed, and the one proposed here can function as a guideline for change. The model must be based on recognitions of the uniqueness of the subcontinent, with an emphasis on linguistic challenges and varied cultural groups and values. Attitude change, awareness and skills development are indexes to ICT acquirements. The reason for focusing on these areas is, as previously stated, the aim of bridging the digital divide. Camacho (2006) explains the digital divide as follows:

- In recent years, as information and communication technologies have become the backbone of the global information economy and given rise to the information society, more attention has been focused on the gap in access to ICT's between developed and developing countries. This gap has been known as the digital divide [15].

\subsection{Digital literacy in the sub-Saharan Africa curriculum (ICT as a separate subject)}

Sub-Saharan Africa has a long way to go until ICT is widely spread into society; the first step is to offer education to all children. The fundament of lifelong learning through ICT will be set through primary school, when e.g. parents become familiar with the use and understand the potential of ICT through their children's work.

Several initiatives and international and national schemes have in recent years introduced ICT into teaching in sub-Saharan Africa with a variable degree of success [17]. The reason that success is limited is due in part to poverty in the region, which places a greater emphasis on basic needs like clean water and medicine, in addition to underdeveloped technical infrastructure as natural consequences of poverty. But it's likely that lack of ICT strategies, combined with insecurity surrounding interpretation of the term digital literacy, are partially to blame. As a response to this, it's advisable that the governments relate to the significance of interpretation of the terminology and include it into their overall strategies.

Despite poverty and deprivation in sub-Saharan Africa, there are several advantages when it comes to ICT integration in education within this area. Even though sub-Saharan Africa faces more, and mostly different, challenges from developed countries, one is free to exploit the opportunity to learn from mistakes and successes made elsewhere and prepare a digital literacy based on the best practices [18]. While awaiting the infrastructure to build up, work against financial constraints and encouragement to proactive policies in education can be conducted. Introduction to free primary education, emphasis on tertiary education and e-policies and strategies customized to each country are other measures. In addition, the school system would get advantage of preparing for education in and through ICT.

In this article the author aims to encourage readers with personal experiences from teaching ICT in Norwegian primary school. Regarding preparation for ICT integration in sub-Saharan Africa, it is recommended that an association for the welfare of the entire region develop a master plan for teaching digital literacy as a separate area of focus as a base for adaptation to local conditions. This model will seek to address the educational program for pupils and teachers: Pupils at certain levels will have a guideline for what to learn, and lessons will be made available. Likewise, teachers' education will have to adjust to the new practices, and the outcome can, amongst other results, establish a curriculum in digital literacy for teachers’ training.

\section{Assumptions of the model's success into sub-Saharan context}

Sub-Saharan Africa is the largest contiguous area of poverty in the world. There are multiple and complex factors involved in the area's bad conditions - several years of colonial deprivation, tribal conflicts and political neglect are identified as the main reasons. The digital divide is a product of the social gaps produced by economic, political, social, gender, generational and geographical inequalities, and it has appeared in the wake of the regions' suffering. Development of ICT in education needs to be customized to conditions in "the South," and introduction of the proposed model with ICT as a separate subject might support the process of bridging the digital divide. There are several prerequisites for success of the implementation into sub-Saharan Africa context, and some of the challenges and opportunities are highlighted in the following sections.

\subsection{Inclusion of all}

One of the most critical challenges in sub-Saharan Africa will be to integrate the entire population in an ICT development process. Women and people in the rural and remote areas are population groups that need extra attention. It's required to strengthen the women's position in sub-Saharan societies, including giving them the opportunity to participate in education. This group plays a crucial role in keeping 
the family and local community going. Camacho (2006) expresses the concept of inclusion this way:

- We renew our commitment to the principle of inclusion: everyone everywhere should be enabled to participate in and no one should be excluded from the benefits of the global information society [15].

Free primary education for all is the fundamental step towards global gender equality. An image of today's reality is that sub-Saharan Africa and Southern Asia are home to the vast majority of children out of school, and inequalities thwart the progress towards universal education. One of the Millennium development goals for education is to "achieve universal primary education" for children all over the world by 2015:

- $\quad$ Ensure that, by 2015, children everywhere, boys and girls alike, will be able to complete a full course of primary schooling [19].

At the summit on the Millennium Development Goals in September 2010, it was stated that the hope for universal education by 2015 dims even as many poor countries make tremendous strides. Despite the belated process, an important future part of development aid will be to provide a realistic model to invite digital literacy into teaching and learning processes in sub-Saharan Africa, in order provide local students the opportunity to enter the communication society in a manner juxtaposed to students in developed parts of the world.

Developing countries are regularly encouraged to invest in their national information infrastructures so that they can participate in knowledge-based development and experience the projected social and economic benefits [20]. This is an essential part of combating the digital divide, and it needs to be included, and highly reflected, through the future Millennium Development Goals. As previously confirmed, digital literacy refers to mandatory knowledge and skills in today's world.

\subsection{Digital literate teachers}

The objective for the school is to educate digitally literate students who have sufficient technological insight for everyday use, and who additionally hold expertise for critical participation in a digital communication society in order to influence the further development of the world. The school and its educators play an important role in this context: They are responsible for educating and clarifying students as citizens. Sehoole and Moja (2003) stress the teacher's central role in the school's ICT development process in this manner:
- Technology is only as good as the people using it. Therefore, effective use of technology in teaching and learning requires well-trained and qualified personnel [21].

Just as important as the inclusion of digital literacy in primary educational services for all, is an emphasis on tertiary education that offers teachers training in and through ICT. In Norwegian schools teachers have become increasingly capable of using ICT tools for administration and organization of teaching, but they still seem to fail to integrate the use of digital tools in the pedagogical everyday life [22]. Unwin (2004) refers to Africa when claiming that "teacher training is all too often neglected in the face of more immediately visible educational goals and objectives." Furthermore, he underlines that "both the quantity of teachers, and the quality of their expertise need to be enhanced" [17].

According to this insight it's obvious that a fundamental change to the worldwide standing of the teacher's role in today's school system has to appear. In order for the students to become literate in a digital world, they need guidance by skilled, available and responsible teachers. ICT educated teachers will hold expertise in monitoring the social development of ICT and thereby be capable of providing students quality-assured educational ICT programs that include methodical progression and variation aligned to the rest of the community services. As digital literacy (or ICT) emerges as a separate subject, it's likely that time (on the students' and teachers' timetables) will be made available and responsible teachers will be devoted to the purpose as a consequence. Furthermore, potential challenges regarding access to ICTs will be met through carefully planned schedules, in which fair sharing of resources is taken into account.

\subsection{Curriculum for digital literacy adapted to local conditions}

In this paper a "best practice" is identified as preparation of a curriculum for digital literacy as a separate area of focus, and the overall plan is recommended to function as a basis for adapting to local conditions. As we know, there are vast disparities in the ways of life in the region. Whether or not people would utilize ICT and find it useful in their lives, one of the main objectives for a local ICT educational plan will be to reflect local characteristics.

Sub-Saharan Africa is represented by multiple cultural groups that might have unique languages. As an example of the linguistic diversity, Gudmundsdottir (2010) points out that South Africa has 11 official languages. Furthermore she expresses that English holds a high status in the country, but 
that use of digital tools in a "regular" subject (guided by the English language) might lead teachers and learners to face a double literacy challenge:

- $\quad$ This implies that learners may not fully comprehend the subject taught in English and with a computer platform and software in English [23].

It's doubtful that the linguistic challenges in subSaharan Africa will drop through English linguistic computer platforms, software and instructions. Such a reality will rather encourage the maintenance of the digital divide. A prerequisite for success of integration of the proposed ICT model into the subSaharan African context in general, and to bridge the digital divide in particular, is production of local language resources. Additionally it's advisable that the sought productions are developed with the aim of assisting the natives in their overall development efforts. Presumably local ICT content in a local language will promote the population groups' peculiarity and identity, and the recognizable factors might contribute positively to the general learning process.

\subsection{A digital literacy that reflects "out of school activity”}

In today's society, people are connected to various social institutions through increasingly integrated media technologies, and these "nodes in a network" illustrate collaboration that enables maintenance of "the global circulation of money, goods, services, symbols and power" [24]. It's obvious that students' technological expertise and habits extend beyond the schools' level of development when it comes to the facilitation of ICT [11]. Based on its mandate, Norwegian basic education is, however, responsible to provide students at all ages equal opportunities to function in a digital society, and work related to ICT should therefore constitute a central area of focus in schools [22].

The social changes in the wake of the introduction of ICT in society have been tremendous. When young people's lives are characterized by extensive use of ICT, and the schools don't reflect this state, it might be profitable to everyone and everything related to the school as a system to modify its recommendation and allow for extended utilization of students autodidact expertise. Thus digital literacy as a subject increasingly will be influenced, performed and controlled by the students themselves, in order to provide them the opportunity to evolve from their own standpoint of expertise and capabilities. The solution may prevent boredom caused by teacher-guided activities that are perhaps far below the student's knowledge level [11].
The school system will probably benefit from changing attitudes towards ICTs, in the sense that "meeting the students at their level" will encourage learning, and skills and knowledge that students obtain through private ICT activities will be easily transferred to similar technologies. A key to obtain digital literacy is to be found in the students "out of school activities.” Relevant in today's sub-Saharan Africa is mobile technology, and different kinds of technological activity will presumably rise as the technological infrastructure emerges. Considering this, it's essential that the proposed "digital literacy for the future" depict local people's ICT habits in the adoption phase of the model and customize the content of curriculum accordingly. Buckingham (2003) emphasizes that the state of being digitally literate is not juxtaposed with skills; it also integrates creativity and increase of awareness. The objective for the school's ICT activity then, is to adapt to how social development at large works:

- In these terms, therefore, the argument for media education is essentially an argument for making the curriculum relevant to children's lives outside school, and to the wider society [3].

\section{Conclusion}

In this article a model for teaching and learning digital literacy in primary schools in sub-Saharan Africa is proposed, and the basic concept is consideration of ICT as a separate subject. The claim that basic ICT skills, or digital literacy, most likely will be accomplished through its own subject is based on the reasoning that newcomers to ICTs, such as schools, are not yet able to deal with the diversity of time, technological infrastructure and expertise. The consequence of the model does not exclude the use of digital tools within other subjects, thus increasing and improving utilization of ICT in general. It's conceivable that both students and teachers through ICT as a separate subject will adapt to the technology and thereby grow more ICT competent, and that their increased knowledge and skills will consequently lead to creativity and excellence in their approach to digital tools. Furthermore it's advisable that the curriculum for digital literacy reflects the student's utilization of ICTs out of school.

Introduction of ICT as a separate subject with specially trained teachers might provide sub-Saharan Africa assistance in the process towards participating in globalized information and economic development. In order to serve developmental goals Mhlanga (2006) claims it's "extremely critical for developing countries not to ignore the new 'technoeconomic' paradigm” [20]. Digital literacy that students obtain during primary education will form 
the basis for understanding of, and influence on, society. Øgrim and Beck claim that effective and safe use of the technology is juxtaposed with knowledge of ICTs position in society; people must achieve the necessary understanding of how ICT acts as part of society in order to participate in the worldwide arena of debate in a safe and constructive way. They also express that the challenges are to be found in the culture and among school leaders and teachers [8]. From this point of view it's essential to put effort into adjustment of the school employee's attitudes to ICTs, so that they will respond immediately to the reality of change, which is here to stay_-and which will continue developing:

\section{- $\quad$ Perhaps the only prediction that can be} offered with certainty is that the impact of technology is irreversible. Specific changes may come and go, literacy and technology seem inextricably linked [9].

The proposed model for teaching and learning digital literacy is primary addressed to sub-Saharan Africa; it is believed, however, that both developed and developing countries will benefit from the essence of this model.

\section{Acknowledgements}

I would like to thank Professor Leikny Øgrim at Oslo and Akershus University College of Applied Sciences for her experience and knowledge sharing in the course "ICT supported development and education in the South." Her patient efforts to provide feedback in the writing process have been invaluable. Furthermore, I appreciate the conversations with and cooperation of my fellow students in the course.

\section{References}

[1] Storsul, T. (2008) 'Nye Nettfenomener - staten og Delekulturen', ITU Research: http://www.itu.no/filestore/Rapporter__PDF/NyeNettfenomener.pdf (11 December 2010).

[2] Fougner, J. and Søbstad, F. (1986) Medielære, Engers Boktrykkeri A/S, Otta.

[3] Buckingham, D. (2003) Media education; literacy, learning and contemporary culture, Polity Press, Cambridge.

[4] Stables, A. (2003) 'Education for Diversity', Ashgate, Alderhof, 2003.

[5] Gilster, P. (1997) Digital literacy, John Wiley and Sons Ltd., New York.
[6] Tyner, K. (1998) 'Literacy in a Digital World: Teaching and Learning in the Age of Information', Lawrence Erlbaum and Associates, New Jersy, pp. 174190.

[7] Erstad, O. (2005) Digital kompetanse i skolen - en innføring, Universitetsforlaget, Oslo.

[8] Øgrim, L. and Beck, E.E. (2009) 'Bruke, forstå, forandre', in Østerud, S., Enter-veien mot en IKT-didatikk, Gyldendal Akademiske, Oslo, pp. 174-190.

[9] McKenna, M.C. et.al. (2006) International Handbook of Literacy and Technology, Routledge, London.

[10] Erstad, O. (2007) 'Den femte grunnleggende ferdighet - noen grunnlagsproblemer’, Norsk pedagogisk tidsskrift 91, p. 43.

[11] Somekh, B. and Mavers, D. (2003) 'Mapping Learning Potential: students' conceptions of ICT in their world', Assessment in education 10 (3), pp. 409-420.

[12] Säljö, R. (2006) Læring og kulturelle redskaper: Om læreprosesser og den kollektive hukommelsen, Cappelen akademiske forlag, Oslo.

[13] ITU Monitor (2009) 'Skolens digitale tilstand 2009', Forsknings- og kompetansenettverk for IT i utdanning; http://www.itu.no/ITU+Monitor+2009+-

+Skolens+digitale+tilstand.9UFRDG0f.ips (1 October 2010).

[14] Skoleporten (2011) 'Ressurser - Materiell', Utdanningsdirektoratet;

http://skoleporten.udir.no/rapportvisning.aspx?enhetsid $=00$ \&vurderingsomrade $=563$ c8f59-e31b-4db1-a533-

7387f58fc430\&underomrade=187afb68-953d-48fe-816370037ce50cf4\&skoletype $=0$ (15 November 2011).

[15] Camacho, K. (2006) Digital divide, http://vecam.org/article549.html (29 May 2011).

[16] Gottschalk, P. ( 2002) IT strategi, Fagbokforlaget, Bergen.

[17] Unwin, T. (2004) 'Towards a framework for the use of ICT in Teacher Training in Africa', The Journal of Open and Distance Education on Open Learning in Less Developed Countries, University of London.

[18] Mutula, S.M. (2004) 'Peculiarities of the digital divide in sub-Saharan Africa', Electronic library and information systems 39 (2), pp. 122-138.

[19] UN (2011) We can end powerty 2015, http://www.un.org/millenniumgoals/education.shtml (26 March 2011).

[20] Mhlanga, F.S. (2006) ‘A developing country's information and communication technology infrastructure in perspective: A vision for the $21^{\mathrm{ST}}$ century', SDPS Journal 10 (1), pp. 71-78.

[21] Sehoole, C.T. and Moja, T. (2003) 'Pedagogical Issues and Gender in Cyberspace Education: Distance 
Education in South Africa', Africa and Asian Studies 2 (4), pp. 475-496.

[22] ITU Monitor (2007) 'Skolens digitale tilstand 2007', Forsknings- og kompetansenettverk for IT i utdanning; http://www.itu.no/ITU+Monitor+2007+-

+Skolens+digitale+tilstand.9UFRnQZp.ips $\quad(1$ October 2010).

[23] Gudmundsdottir, G.B. (2010) 'When does ICT support education in South Africa? The importance of teachers' capabilities and the relevance of language', Information Technology for Development 16 (3), pp. 174190.

[24] Østerud, S. and Knudsen I.M. (2009) 'Rom og tid i didaktiske modeller', in Østerud, S., Enter-veien mot en IKT-didatikk, Gyldendal Akademiske, Oslo, pp. 33-57. 